\title{
From Perfection to performance: A Moderated Mediation process
}

\author{
Hira Rani Shaikh ${ }^{1, *}$, Syed Mir Muhammed Shah ${ }^{1}$, Muzafar Hussain Shah ${ }^{2}$ and Asif \\ Nawaz ${ }^{1}$ \\ ${ }^{1}$ Business Administration Department, Sukkur IBA University, Sukkur Sindh, Pakistan \\ hirarani.sweet@gmail.com; syedmir@iba-suk.edu.pk; asif.phdmgt18@iba-suk.edu.pk \\ ${ }^{2}$ School of Business Management, Universiti Utara Malaysia, Sintok, Malaysia \\ Syedmuzafar110@gmail.com \\ *Correspondence: hirarani.sweet@gmail.com
}

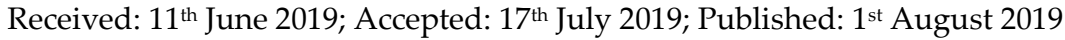

\begin{abstract}
The Present study empirically examines the impact of perfectionist striving on active behavior and task performance. Work motivation used as a mediating mechanism and basic psychological needs employed as a moderator between perfectionist striving and workplace behaviors. It's a moderated mediating study because of the interest of knowing the conditional nature of mediating variable. Self-determination theory has been employed as theoretical background of these relationships in order to have full and thorough understanding of the link from perfection to performance. Data were collected from 220 subordinatessupervisor matching dyads of engineers from different organizations of Pakistan using convenient sampling technique. Exploratory factor analysis and hierarchical regression used to check the direct relationships. Indirect macro used for mediating relations and process macro used for moderating relation of the study. Results supported the positive association of perfectionist striving with task performance and proactive behaviour. Furthermore, results also supported the mediating effect of work motivation. However, results could not predict the moderating role of basic psychological needs. Moreover, findings of present research bring an important implications for organizations to consider perfectionism as positive attitude because it relates to adaptive outcome and positive work behaviours such as performance.
\end{abstract}

Keywords: Technology Perfectionism; Task performance; Self-determination theory; Proactive behaviour; Work motivation

\section{Introduction}

Perfectionism refers to positive characteristic of one's personality where every person strive for perfection, therefore, set very high standard of performance for one's own self, (Flett \& Hewitt, 2002; Frost, Marten, Lahart, \& Rosenblate, 1990). Perfectionism is a quality that contributes to every walk of life, especially work which could influence the social relations and the outlook of all individuals (Stoeber \& Stoeber, 2009). Hence, it has received enormous attention since 1990s (Blatt, 1995; Hollender, 1978; Pacht, 1984). Firstly it was introduced as one-dimensional in nature (Burns, 1980), but later on its nature become changed and it became multidimensional construct (e.g., 
Multidimensional Perfectionism Scale) (Frost, Marten, Lahart, \& Rosenblate, 1990; Hewitt \& Flett, 1991). According to different scholars, perfectionism has been differentiated into two major dimensions named as perfectionist striving and perfectionist concern(Frost, Heimberg, Holt, Mattia, \& Neubauer, 1993; Stoeber \& Otto, 2006). Perfectionist striving is concern with setting high performance standards. It is self-oriented in nature. On the other hand, perfectionist concern is negative in nature. It capture facets of perfectionism such as negative feelings of incongruence between one's expectations and outcome, doubt about actions, fear regarding evaluation of performance and much more. In short, perfectionist concern is associated with negative outcomes and negative effect (see further Stoeber \& Otto, 2006).

\section{Literature Review}

\subsection{Overview of the Concepts}

Differentiation between perfectionist striving and perfectionist concern is equally worth able when linking perfectionism to performance. While perfectionist concern have not revealed any significant relationship with performance, much research has explored positive association of perfectionist striving with performance such as such as academic goals like mastery and achievement goals (Stoeber \& Rennert, 2008), academic performance (Stoeber and Scott, 2015; Accordino \& Slaney, 2000; Bieling, Israeli, Smith, \& Antony, 2003; Stoeber \& Rambow, 2007), athletes sports performance (Stoeber et al., 2012), musician's performance (Stoeber \& Eismann, 2007) and much more.

However, as performance of employees is very much crucial element which causes organizational success, the link between perfectionist striving and task performance of employees is very much limited (Stoeber \& Childs, 2010) and according to Stoeber (2014), much attention is needed to assess the impact of perfectionist striving on one's performance because some researchers have argued that achievement of high level of performance by perfectionist striving can be unfavorable in maintaining performance due to its tendency to generate negative result such as burnout or depression to achieve high standards.

Therefore, considering the conceptualization of perfectionism and the importance that perfectionists put on high standards of performance (Flett \& Hewitt, 2002; Frost et al., 1990), it comes as a surprise that until recently research on perfectionism has largely ignored how perfectionism relates to task performance (Stoeber, 2012). Therefore, despite of its importance by keeping in view the missing link, this research has been intended to empirically investigate the effect of perfectionist striving on task performance.

Research about perfectionist striving suggests that people having quality of perfectionist striving always look for excellence with focus on actions that improve themselves and bring positive changes in personality (Stoeber, 2008; 2010; 2015) and Proactive behavior usually stresses the importance on self-initiated and future-prescribed action whose intention is to perk up the current status quo and bring positive change in personality (Crant, 2000; Unsworth \& Parker, 2003). As work has become more vigorous and dispersed, proactive behavior and initiatives have become fundamental blocks for the success of organization(Frese, Fay, Hilburger, Leng, \& Tag, 1997).

According to Crant (2000), people with proactive behavior opt for a situation that increase their likelihood of attaining higher level of job performance (Crant, 2000). Researchers have studied proactive behavior in organization using different antecedents such as personality \& work environment (Parker, Williams, \& Turner, 2006); job stressors (Fritz \& Sonnentag, 2007); individual differences and contextual factors (Crant, 2000). However, akin to the link of perfectionist striving and task performance, there is Lacuna in scholarly underpinnings on the link between perfectionist striving and proactive behavior. Therefore, considering the significance of task performance and proactive behavior towards success of organization, present research has been intended to address the research gap by empirically examining the effect of perfectionist striving on task performance and proactive behavior. Doing so would enable this study to bring forth two-folded contributions.

First, although, we argue that people with perfectionist striving try to excel themselves in performing their task and they always behave in a proactive manner but very few studies have 
examined about 'mediating instruments'(Frazier, Tix, \& Barron, 2004) that cause the striving for perfection and performance relationship. The few explored mediating variables are invested time on task (Stoeber, Chesterman, \& Tarn, 2010), perceived pressure to be perfect (Stoeber\& Renner, 2008) and achievement goals (Stoeber et al., 2015). However, in the present research, work motivation has been employed as a mediator that cause perfectionist striving and performance relationship because Stoeber, (2013) argued that work motivation is a variable that elaborate the positive association of perfectionism with workaholism and other positive work behaviors because perfectionists always work with determination and motivation which in turn leads towards positive performance (Galdeano, Ahmed, Fati, Rehan \& Ahmed, 2019). This argument has been further strengthen by other researchers(Hall, Hill, \& Appleton, 2012; Mills \& Blankstein, 2000; Stoeber, Feast, \&Hayward, 2009; Van Yperen, 2006) who have confirmed the significant positive association of perfectionist striving with motivation and all types (introjected regulation, identified regulation, intrinsic motivation and extrinsic motivation) proposed by self-determination theory (SDT), suggesting that perfectionist are highly motivated through the variety of motivations.

Moreover, Van Knippenberg (2000) have also claimed that work motivation strongly influence work behavior because it is an element through which employee's perform sound on their jobs. Therefore, we have included work motivation as a mediating mechanism in that relationship because perfectionist have shown to be highly motivated (Damian, Stoeber, Negru, \& Băban, 2013) hence we argue that their motivation enhance their performance and motivates them towards adopting proactive behavior.

Second, start from the period of Maslow (1943) to McGregor (1960) who initialized needhierarchy theory in the management field, much has been discovered regarding the association of human needs with work motivation and job behaviors (Gagné \& Deci, 2005). The reason to understand the idea of need being so attractive to date can be its intensive usefulness for describing the range of environment that might be expected, important, to cause positive versus adverse outcomes (Gagné \& Deci, 2005). Many researchers have argued that needs are central cause of human behavior (Latham, Ganegoda, \& Locke, 2011).

Majority of research has confirmed the association of basic psychological needs with positive outcomes such as well-being (Blankstein \& Winkworth, 2004; Deci \& Ryan, 2008; Vansteenkiste, Simons, Lens, Sheldon, \& Deci, 2004), psychological functioning (Ryan \& Deci, 2000), motivation (Ilardi, Leone, Kasser, \& Ryan, 1993; Richer, Blanchard, \& Vallerand, 2002) and health-behavior change (Williams et al. 2009). Therefore, based on the above arguments, present study incorporates basic psychological needs as a moderator between striving for perfection and work motivation by arguing that satisfaction of three needs create work motivation for people with perfectionist striving which in turn increases their task performance and work behavior especially proactive behavior.

\subsection{Perfectionist Striving}

Perfectionist strivings is defined as "aspects of perfectionism associated with a self-oriented strive for perfection, a commitment to exceptionally high personal standards. It encompasses facets of perfectionism that are typically considered normal, adaptive, and healthy" (Stoeber \& Otto, 2006, p:249; Stoll, Lau, \& Stoeber, 2008).Perfectionist striving is associated with setting high standard of performance(Stoeber, 2014). It is self-oriented in nature because it captures only those elements of perfectionism that has close connection with perfectionist standard and its relation has mostly found with positive process and outcome (Madrid, Ahmed \& Kumar, 2019; Stoeber \& Childs, 2010). Researchers have argued that perfectionist striving have close links with higher academic performance, positive characteristics, affect, processes and outcomes (Stoeber, Uphill, \& Hotham, 2009). As per the views of Stoeber (2014), Perfectionist strivings are negatively linked with anxiety and positively linked with self-confidence thereby suggesting that peoples who strive for perfection approach competition with a positive conviction that may help them achieve a higher performance. Furthermore, Stoeber (2008) have argued that perfectionist striving concerns with those selected characteristics that helps to boost one's performance. 


\subsection{Task Performance}

According to Griffin, Neal, and Neale (2000), "Task performance means those technical behaviors and activities that are concerned with the job for example: formal job role. Task performance basically describes the specific behaviors of individuals which can be distinguished only in term of effectiveness means the impact that behaviors have on the outcomes that are valued by the organization" (Motowildo, Borman, \& Schmit, 1997, p: 86). Task performance is objective towards the effect of situational restraints, because it is firmly synchronized and regulated by the organization (Griffin et al., 2000).In short, transforming raw material into finished products and services that are explicit to the job is said to be the task performance, means the core technical skills.

\subsection{Perfectionist striving and Task performance}

Previous literature has discovered much more regarding the positive association of perfectionist striving with performance for thorough understanding of how perfectionism influences on individuals and their performance. Findings have also supported the relationship of such striving with higher academic performance of individuals (Bieling, Israeli, Smith, \& Antony, 2003; Stoeber \& Kersting, 2007; Stoeber \& Rambow, 2007) and musical settings (Pahi, Hamid, Ahmed \& Umrani, 2015; Stoeber \& Eismann, 2007).

Moreover, literature informs about few recent related studies that have investigated the relation of perfectionist striving and different type of performance (Bieling, Israeli, Smith, \& Antony, 2003; Slade, Newton, Butler \& Murphy, 1991; Stoeber \& Eismann, 2007; Stoeber \& Eysenck, 2008). The few investigated studies are searching of letter task (Slade et al., 1991); exam performance of undergraduates (Bieling et al., 2003); talented musician's performance (Stoeber and Eismann., 2007)and proof reading performance of undergraduates (Stoeber and Eysenck., 2008). Findings revealed that only those respondents were higher on task performance that was high on perfectionism. Consequently, according to Stoeber and Childs (2010) "there is also much confirmation available suggesting the association of perfectionist striving with higher level of performance across different domains and various tasks, from simple laboratory tasks to real-world exams and competitions" (p: 04).

Stoeber and Eismann (2007) and Stoeber and Eysenck (2008) have also confirmed that perfectionist strivings are supposed to lead towards higher level of performance just because people who strive for perfection spend more time on performance as compared to those who spend less time on it. Stoeber (2014) have further strengthen the above mentioned argument by claiming that perfectionist strivings are allied with small amount of mental depression and anxiety and large amount of self-confidence indicating that contestants who go for perfection achieve competition with positive mentality which in turn help them attaining higher performance. Therefore, considering the above discussion, this study argues that:

H1: Perfectionist striving has direct positive association with task performance.

\subsection{Proactive Behaviour}

The creation of novelty and innovations always demand diligent and self-starting direction from employees and forced them to be creative and more innovative (Parker et al., 2006). These proactive behaviors pushes employees towards favorable outcomes such as small-firm innovation (Prather \& Turrell, 2002), sales performance (Crant, 1995), entrepreneurial behaviors (Becherer \& Maurer, 1999) and individual innovation (Seibert, Kraimer, \& Crant, 2001). Proactive behaviors entails an active attitude toward work (Frese et al., 1997; Parker et al., 2006) and have the intention to improve and modify given methods of work and develop personal characteristics to meet future demands of work. It includes behaviors like personal initiative (Frese, Kring, Soose, \& Zempel, 1996) and taking charge (Ahmed, Mozammel \& Ahmed, 2018; Morrison \& Phelps, 1999). These variables has also been discussed by Parker et al. (2006). Thereby supporting the argument that proactive behavior is very much essential for today's modern organizations in order to bring change and decrease supervision. Organizations need employees who approach more than general task requirements through taking 
initiatives in order to meet today's customer's demands, to show flexibility and to compete in this global era (Crant, 2000; Frese et al., 1996; Parker et al., 2006).

\subsection{Perfectionist striving and Proactive Behaviour}

Researchers have argued that perfectionist always try for excellence and they focus on actions that improve themselves and bring positive changes in personality and Proactive behavior normally emphasis on these future-oriented and self-initiated behaviors that modify and improves person and their situation as well (Crant, 2000; Unsworth \& Parker, 2003). Connecting the above argument, it has been argued that people with perfectionist striving mostly intended towards proactive behavior in order to improve their working situations just because they possess dedicated nature regarding their work (Ahmed, Majid, Al-Aali \& Mozammel, 2019). Moreover, people with perfectionist striving, as argued by Stoeber, Feast, et al. (2009), are associated with hope of success regarding their achievement situations therefore they "take an active role in their approach toward work; they initiate situations and create favorable conditions" (Crant, 2000, p: 436). Following this lead, this study argue that those who strive for perfection will always be proactive in their behavior because their mind has been set towards improvement and initiatives that may help them in achieving high standard performance. Thus it has been anticipated that:

H2: Perfectionist striving has direct positive association with proactive behavior

Two main ingredients of every work environment like critical strategic asset and competitive advantage can be best represent only by motivated work force. According to the views of Baron (1991), work motivation has got enormous attention than any other topic in organizational research because researchers from the field of organization, consider work motivation as a building block in human development (Campbell, 2007). And that is one of the reason that Tremblay et al., (2009)"considered work motivation as mysterious topic of research in work and organizational science" (p: 01).

\subsection{Mediation of Work Motivation}

Although based on the arguments made above that perfectionist striving people go for positive work behaviors but question is still unanswered that how they go for these types of behavior. That is why, the framework of self-determination theory (Deci \& Ryan, 2002) have been incorporated. According to Tremblay et al. (2009)Self-determination theory is normally applicable to those undertakings which are pleasing, challenging and interesting. "Activities, which are not experienced as such, work for example, are unlikely to be performed unless there is, to some extent, a reason/motivation for doing them" (p: 214).Using this theory different studies were reviewed for getting the answer of above mentioned question that how quality of striving for perfection leads people towards high task performance. According to the study of Damian et al. (2013), one possible element through which perfectionism go towards positive work related consequences is the motivation because perfectionist striving are shown to be highly motivated towards their work and their motivation leads them towards positive work related behavior (Ahmed, Khalid, Islam \& Abro, 2019). This argument has been further strengthen by De Dreu, Nijstad, and van Knippenberg (2008) as they argued that the main factor that affects performance is work motivation to perform well on the job.

Different research scholars have also used work motivation as a mediating mechanism between perfectionism and different work related behavior using self-determination theory (Ryan \& Deci, 2000) such as workaholism(Damian et al., 2013; van Beek, Taris, \& Schaufeli, 2011) performance (Van Knippenberg, 2000) burnout and engagement (Van den Broeck et al., 2008).Hence, keeping in view the arguments of Damian et al. (2013) and De Dreu et al. (2008), this study argue on the basis of selfdetermination theory (Ryan \& Deci, 2000) that the interest of perfectionist striving to achieve high standard performance in their work creates work motivation for them which in turn leads them towards positive work related behaviors such as high task performance and proactive behavior because they are motivated by their interest in an activity (Gagné \& Deci, 2005) and their motivation 
further create more chances for adopting proactive behavior and high performance on their task. Thus, it has been anticipated that:

H3a: Work motivation mediates the relationship between perfectionist striving and task performance.

H3b: Work motivation mediates the relationship between perfectionist striving and proactive behavior.

\subsection{Moderating role of basic psychological needs}

According to the views of many scholars, needs have been considered as basic ingredients of human behavior (Broeck et al., 2010; Latham \& Pinder, 2005). According to self-determination theory (Broeck et al., 2010; Deci \& Ryan, 2008; Ryan \& Deci, 2000) there are three basic needs that are required by all individuals to flourish. These are need for autonomy (i.e., possessing a sense of freedom), need for competence (i.e., a sense of feeling own self capable and effective) and need for relatedness (i.e., feeling loved and cared) (p: 981). According to Ryan and Deci (2003), self-determination theory is developmental for all humans because goals, values and behaviors can be integrated, connected or organized within one's own self (Galdeano, Ahmed, Fati, Rehan \& Ahmed, 2019).

In self-determination theory, satisfaction of basic needs is considered as motivational mechanisms that controls and regulate the behavior of all peoples (Ryan \& Deci, 2000). along these lines, Faye and Sharpe (2008) further argued that surroundings and locations that provide the fulfillment of these needs produce self-determined behaviors and intrinsic motivation. The main idea of this study is that, basic psychological needs moderate the mediating effect of work motivation between perfectionist striving and positive work place behaviors (task performance and proactive behavior). The reason has been highlighted by Gagné and Deci (2005) that environment that encourage satisfaction of these needs will ultimately increase the intrinsic motivation of employees and will further promote thorough internalization of extrinsic motivation which in result give the positive work related consequences such as persistence \& maintained behavior change, job satisfaction, organizational citizenship behavior, psychological adjustment and wellbeing, positive work related attitudes and behavior and effective performance on tasks.

Moreover,Stoeber (2014) have further argued that individuals who strive for perfection achieve competition with a positive mentality with respect to their achievements because they are always linked with positive hope for success that may help them achieve higher performance.

Following this lead, it has been argued that fulfillment of basic psychological needs creates further work motivation for people with perfectionist striving that may guide them towards achieving high task performance and adopting proactive behavior. Thus, on the basis of selfdetermination theory by connecting the above mentioned arguments of Stoeber (2014)it has been anticipate that:

H4a: Basic psychological needs moderates the mediating effect of work motivation between perfectionist striving and task performance such that this mediating effect is stronger when needs are fulfilled at high level as compared to low.

H4b: Basic psychological needs moderates the mediating effect of work motivation between perfectionist striving and proactive behavior such that this mediating effect is stronger when needs are fulfilled at high level as compared to low.

\section{Methodology}

\subsection{Research Context:}

Research context basically refers to a setting where research has been actually conducted. This research has been conducted in Pakistan. Focused population for this research was engineers because as far as engineer's profession is concerned, they don't just work with machines, design or circuit board but they have to be clear with the context and surroundings where they work. They have to be perfect in their every work and design because they have to make ensure to society that work is safe 
\& will not disturb environment. Their true happiness lies in the design. Better design makes them happier until it reaches a point (near to perfection). That is the reason behind selecting this sample.

\subsection{Sampling}

A quantitative questionnaire survey was conducted from engineers who were selected from different reachable cities of Pakistan using a dyadic technique. Questionnaires were distributed directly (face to face) to engineers and their immediate boss. Cover letter, explaining the motive of the study, was also used for getting permission from organizations. Questionnaires were in English language because it is the official language of Pakistan and many scholars (Arain, Hameed, \& Farooq, 2012; Raja, Johns, \& Ntalianis, 2004) have also declared that English has been best understood by working population so all the items of it were communicated properly to participants for their easiness \& convenience (Ahmed, Isa, Majid, Zin, \& Amin, 2017). It was also ensuring through direct involvement of researchers that data will be kept confidential \& anonymous. A convenience sampling approach was used because of its convenience and practicality. This approach not only gives access to a wider survey population, but it also allows the questions arising from the survey to be addressed on the spot (Cavana et al. 2001). Strengthening the above mentioned argument, North and De Vos (2002) claimed that "convenience sampling is the rational choice in cases where it is impossible to identify all the members of population" (p.191).

Since it was dyadic study so the data regarding work motivation, perfection and basic psychological needs were collected from engineer employees however their performance rating were collected from their immediate boss. Both questionnaires were paired with same codes but names of employees and their supervisors were erased later on in order to maintain ethics. Total 280 questionnaires were distributed out of which 228 received. 8 were unmatching dyads so could not include. And final data set was of 220 respondents with a response rate of $78 \%$. Total 220 subordinates and 97 supervisor/immediate boss were involved. Each supervisor was required to rate up to 4 subordinates.

\subsection{Measures}

All five constructs involved in this study except demographics were measured using five point Likert scale ranging from " 1 " for "Never" to " 5 " for "Always". Reliability of all 4 scales was also checked before using it in our study. Perfectionist striving was measured using 5 item scale developed by Stoeber and Rambow (2007). Stoeber (2014), Stoeber and Childs (2010) and Stoeber (2012) have also referred same scale. Cronbach alpha for this scale is .82. Sample item is "I strive to be as perfect as possible".

Accordingly, work motivation was measured using 12 item scale of four dimensions developed by Gagné et al. (2010). But after conducting focus group we selected 6 items ( 3 of identified regulation and 3 of introjected regulation) as per the context of our research. Cronbach alpha for this scale is .61. Sample item is "I choose this job because it allows me to reach my life goals (identified motivation)", "Because my work is my life and I don't want to fail (introjected regulation)". Accordingly, task performance was measured using 11 item scale developed by Greenhaus, Parasuraman, and Wormley (1990). Study of Tsui and Tripoli (1997) have also referred this scale. Cronbach alpha for this scale is .76. Sample item is "His/her quantity of work is higher than average". Proactive behavior was measured using 10 item scale which is the shortened version of Bateman and Crant (1993). Previous researches have already demonstrated its reliability as Parker et al. (2006) and Crant (2000) also referred the same scale for measuring the proactive personality of employees. Cronbach alpha for this scale is .78. Sample item is "I excel at identifying opportunities". Basic psychological needs was measured using 22 item scale of three dimension developed by Ilardi et al. (1993). This scale was also used by Broeck et al. (2010)Broeck et al (2010). Cronbach alpha for this scale is 75. Sample item is "I feel free to express my ideas and opinions in this job (need for autonomy)", "I really master my tasks at my job (need for competence)" and "At work I feel part of a group (need for relatedness)". 
Control Variables Along with the main variables in our model, we included variety of control variables in order to hold their effect such as Gender, age, education, organization and experience. But after conducting analysis, what we found is that no any control variable was showing significant effect on main variables (see table 1 in appendix) so we proceed for further analysis without including them.

\subsection{Data Screening:}

According to researchers like (Hair, Black, Babin, \& Anderson, 2010; Hameed, Roques, \& Arain, 2013; Pallant, 2007; Tabachnick \& Fidell, 2007), every data should be screened out before moving for any statistical analysis because the data, if not screened properly, can destroy the results. Therefore, it was necessary for us to make the data normal from all types of errors like aberrant, missing value or outlier.

We started screening the data through detecting values that were out of range means aberrant values (those values that were less than 1 and greater than 5). In this study, we could not found any case of it. After checking the aberrant values we moved towards finding outliers and for getting the normal distribution of data, all other cases where outliers were found were deleted from data file and at last test of normality was observed on remaining cases of data set that were 202 in order to check the normal distribution of data. Descriptive statistics results indicate that most of the items of data were normally distributed because the values of kurtosis and skewness were in the range between +1 and -1 except few items whose kurtosis values lie to the range of -1.5 . The results of descriptive statistics and correlation are given in Table 1.

Table 1: Descriptive Statistics and Correlations

\begin{tabular}{|c|c|c|c|c|c|c|c|c|c|c|c|c|c|c|}
\hline & & Mean & SD & 1 & 2 & 3 & 4 & 5 & 6 & 7 & 8 & 9 & 10 & 11 \\
\hline 1 & Department & N.A & N.A & & & & & & & & & & & \\
\hline 2 & Gender & N.A & N.A & -.082 & & & & & & & & & & \\
\hline 3 & Age & 35.5 & 8.90 & -.060 & -.100 & & & & & & & & & \\
\hline 4 & Organization & N.A & N.A & -.044 & -.048 & $-.158^{*}$ & & & & & & & & \\
\hline 5 & Education & N.A & N.A & .106 & -.080 & .060 & -.100 & & & & & & & \\
\hline \multirow[t]{2}{*}{6} & Experience & 8.88 & 6.88 & .003 & -.112 & $.842^{* *}$ & - & .050 & & & & & & \\
\hline & & & & & & & $.171^{*}$ & & & & & & & \\
\hline 7 & PB & 3.56 & .811 & -.128 & .039 & .008 & .042 & -.023 & .099 & & & & & \\
\hline \multirow[t]{2}{*}{8} & PS & 3.86 & .892 & - & .080 & .076 & .048 & & .114 & $.322^{* *}$ & & & & \\
\hline & & & & $.239^{* *}$ & & & & $.152^{*}$ & & & & & & \\
\hline 9 & $\mathrm{TP}$ & 3.57 & .781 & -.044 & .033 & -.039 & .095 & .026 & .029 & $.187^{* *}$ & $.205^{* *}$ & & & \\
\hline & BPN & 2.98 & .915 & .126 & -.062 & .110 & -.084 & .084 & .017 & .053 & -.027 & .013 & & \\
\hline & WM & 3.51 & .776 & -.080 & .004 & -.026 & .032 & -.034 & .085 & $.380^{* *}$ & $.333^{* *}$ & $.230^{* *}$ & .069 & \\
\hline
\end{tabular}

$* *=\mathrm{p}<0.01$ level, ${ }^{*}=\mathrm{p}<0.05$ level, $\mathrm{PB}=$ Proactive Behavior, $\mathrm{PS}=$ Perfectionist Striving, $\mathrm{TP}=$ Task Performance, $\mathrm{BPN}=$ Basic Psychological Needs, $\mathrm{WM}=$ Work Motivation

After screening the data file from all errors, exploratory factor analysis was observed and we found some cross loaded and low loading items that were later on excluded from further analysis. We dropped five items of task performance, three items of work motivation, three items of proactive behavior and sixteen items of basic psychological needs. The five components depicted a total variance of $57.2 \%$. We also checked the validity and reliability of these items as per the suggested criteria of Hair et al. (2010), that the reliability can be better assessed when the value of composite reliability is greater than 0.70 , whereas convergent validity can be better assessed when AVE (average variance extracted) is greater than 0.50 and discriminant validity can be better assessed when MSV (maximum shared squared variance) \& ASV (Average shared squared variance) is less than AVE (P: 
801-802). After conducting the reliability analysis, results showed that all constructs employed in this research had reliability, convergent validity and discriminant validity as exhibited in the table 2 .

Table 2: Reliability and Validity

\begin{tabular}{lrrrr}
\hline Variables & $\begin{array}{c}\text { Composite } \\
\text { Reliability }\end{array}$ & $\begin{array}{c}\text { Average } \\
\text { variance } \\
\text { extracted }\end{array}$ & $\begin{array}{c}\text { Maximum } \\
\text { shared } \\
\text { variance }\end{array}$ & $\begin{array}{c}\text { Average } \\
\text { shared } \\
\text { variance }\end{array}$ \\
\hline PB & 0.79 & 0.50 & 0.15 & 0.07 \\
PS & 0.87 & 0.57 & 0.09 & 0.05 \\
TP & 0.84 & 0.52 & 0.05 & 0.03 \\
BPN & 0.84 & 0.48 & 0.01 & 0.00 \\
WM & 0.72 & 0.39 & 0.15 & 0.07 \\
\hline PB = Proactive Behavior, PS= Perfectionist Striving, $\quad \mathrm{TP}=$ Task \\
Performance, BPN = Basic Psychological Needs, WM $=$ Work \\
Motivation
\end{tabular}

\section{Results}

In hypothesis 1, we anticipated the positive association of perfectionist striving with task performance. The results presented in table 3 showed that perfectionist striving has significant positive association with task performance as $(\beta=.167$ and $p=.018)$. Therefore, results supported the relation depicted in hypothesis 1.

Table 3: Regression Weights

\begin{tabular}{lccccc}
\hline \multirow{2}{*}{ Variable } & \multicolumn{2}{c}{ Task performance } & \multicolumn{2}{c}{ Proactive behavior } \\
\cline { 2 - 6 } & B & P & B & P \\
\hline $\begin{array}{l}\text { Independent variable } \\
\text { Perfectionist striving }\end{array}$ & .167 & & .018 & .306 & .000 \\
$\mathrm{R}^{2}$ & & .028 & & & \multicolumn{2}{c}{.093} \\
& & & & &
\end{tabular}

In hypothesis 2, we anticipated the positive association of perfectionist striving with proactive behavior. The results presented in table 4 showed that perfectionist striving has significant positive association with proactive behavior as $(\beta=.306$ and $p=.000)$. Therefore, results also supported the depicted relation in hypothesis 2.

Table 4: Mediation Results

\begin{tabular}{lcccccccc}
\hline & \multicolumn{3}{c}{ Proactive behavior } & \multicolumn{3}{c}{ Task performance } \\
\cline { 2 - 7 } & B & SE & P & B & SE & P \\
\hline $\begin{array}{l}\text { Total effect of PCB (c path) } \\
\text { Direct Effect (c' path) }\end{array}$ & .2904 & .0640 & .0000 & .1507 & .0630 & .0176 \\
$\begin{array}{l}\text { Indirect Effect (a \& b paths) via Work } \\
\text { motivation }\end{array}$ & .0920 & .0280 & .0010 & .0504 & .0227 & .0264 \\
\hline
\end{tabular}

In hypothesis3a, we anticipated that work motivation mediates the relationship between perfectionist striving and task performance. We tested this mediation through indirect macro suggested by Preacher and Hayes (2008). Results given in table 4 showed that the indirect effect of 
perfectionist striving on task performance via work motivation is significant as $(\beta=.0504$ and $p=.0264)$. Therefore, hypothesis 3a supported.Preacher, Rucker, and Hayes (2007)

Table 5: Moderation Results

\begin{tabular}{|c|c|c|c|c|c|}
\hline \multirow{2}{*}{$\begin{array}{l}\text { Simple } \\
\text { Moderating } \\
\text { Effect }\end{array}$} & \multicolumn{5}{|c|}{ Task performance } \\
\hline & $\beta$ & S.E & LLCI & ULCI & R-sq \\
\hline PS & .2687 & .0589 & .1526 & .3849 & \multirow{3}{*}{.102} \\
\hline $\mathrm{BPN}$ & .0790 & .0562 & -.0319 & 1900. & \\
\hline PS*BPN & -.0474 & .0730 & -.1913 & .0964 & \\
\hline \multicolumn{6}{|c|}{ Conditional indirect effects of PS on WM on the values of BPN } \\
\hline$-1 \mathrm{SD}$ & & & & & \\
\hline Mean & & & & & \\
\hline$+1 \mathrm{SD}$ & & & & & \\
\hline
\end{tabular}

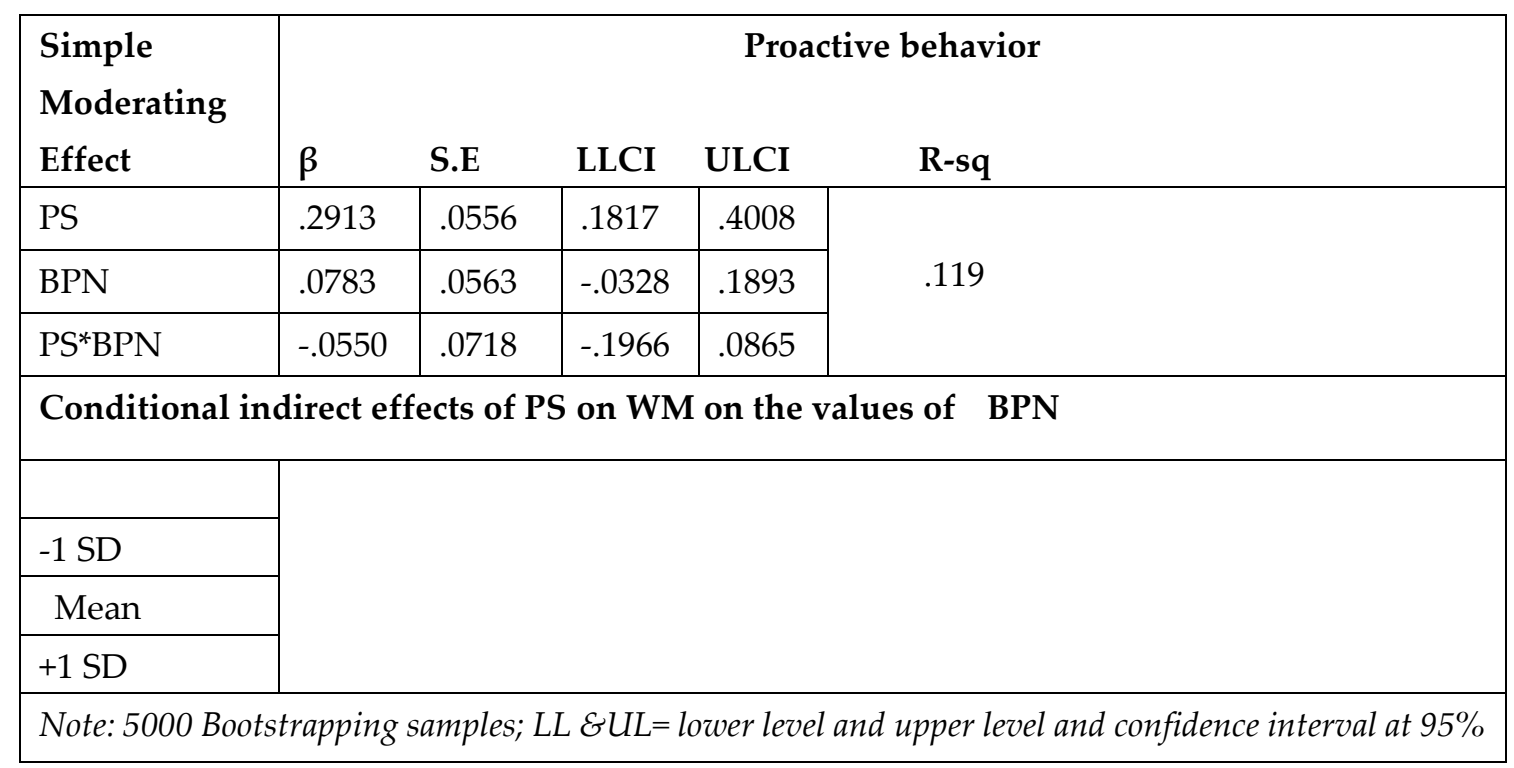

In hypothesis $3 \mathrm{~b}$, we anticipated that work motivation mediates the relationship between perfectionist striving and proactive behavior. We also checked this mediation through indirect macro suggested by Preacher and Hayes (2008). Results given in table 4 showed that indirect effect of perfectionist striving on proactive behavior via work motivation is also significant as $(\beta=.0920$ and $\mathrm{p}=.0010$ ). Therefore, this mediation is also supported by results.

In hypothesis $4 a$, researcher anticipated that basic psychological needs moderates the mediating effect of work motivation between perfectionist striving and task performance as this mediating effect is stronger when satisfaction of needs is high as compared to low. We tested this moderated mediation by following the method of Preacher et al. (2007) using PROCESS macro for SPSS by Hayes (2013). The results of Table 5 showed that basic psychological needs did not moderate the mediating effect of work motivation between perfectionist striving and task performance because the results of conditional indirect effect were not significant as $(\beta=-.047, \mathrm{p}=>.05)$ therefore hypothesis 4 a was not supported.

In hypothesis $4 \mathrm{~b}$, we anticipated that basic psychological needs moderates the mediating effect of work motivation between perfectionist striving and task proactive behavior as this mediating effect is stronger when satisfaction of needs is high as compared to low. We tested this moderated 
mediation by following the method of Preacher et al. (2007) using PROCESS macro for SPSS by Hayes (2013).The results of Table 5 showed that basic psychological needs did not moderate the mediating effect of work motivation between perfectionist striving and proactive behavior because the results of conditional indirect effect were not significant as $(\beta=-.0550, p=>.05)$ therefore hypothesis $4 \mathrm{~b}$ was also not supported.

\section{Discussion}

This study has been basically designed to check the direct as well as indirect effect of perfectionist striving on positive workplace behaviors such as task performance and proactive behavior through using work motivation as mediator and basic psychological needs as moderator. This study supported hypothesis 1 which was about the positive association of perfectionist striving with task performance as its result was significant. Results of this study are consistent with the results of Stoeber and Childs (2010) and Stoeber and Otto (2006) as they also found the significant results in which the perfectionist striving predicted higher task performance. Our findings thereby further confirm the evidence that people with high striving for perfection work with soul, invest more than required efforts thereby achieve higher task performance. Our findings are also in line with the studies of Slade et al. (1991), Bieling et al. (2003) and Stoeber and Rambow (2007). These studies also predicted that people who strive for perfection achieve higher performance on task. Moreover, findings further confirm the caution of Stoeber (2014) who argued that perfectionist strivings are allied with small amount of mental depression and anxiety and large amount of self-confidence indicating that contestants who go for perfection achieve competition with positive mentality which in turn help them attaining higher performance.

In personality psychology, the idea of perfectionism has received much attention from many years but only few handsome studies has explored its effect on normal workplace that how it works there and how it encourage peoples towards initiatives and proactive behavior (Nekoie-Moghadam, Beheshtifar, \& Mazrae-Sefidi, 2012). Researchers like Parker (2000) argued that individuals who define their task largely feel responsibility to achieve long term goals hence they are more motivated to engage in proactive behavior which in turn help them to attain their goals. Our supported hypothesis 2 which was about the positive association between perfectionist striving and proactive behavior thus confirm the above mentioned arguments by claiming that people with perfectionist striving possess courage, confidence and capability thereby feel responsibility to achieve higher performance therefore they have more focus towards adopting proactive behavior because that behavior involve using initiatives and individuals with perfectionist striving mostly look for initiatives and improved ways in order to get perfection in their work.

Accordingly, organizational behavior researchers have argued that the study of work motivation and performance is one of the key issues of today's environment because this motivation has now been proved as significant variable that effects performance Van Knippenberg (2000). Considering this argument we anticipated the mediating effect of work motivation between perfectionist striving and task performance and proactive behavior and our results also supported the mediating effect of work motivation between perfectionist striving and positive work behaviors like task performance and proactive behavior. Our results are consistent with the results of Damian et al. (2013) who found the significant mediating effect of identified and introjected regulation between perfectionism and workaholism. Our results are also in line with the studies of Damian et al. (2013), van Beek et al. (2011), Van Knippenberg (2000) and Liang, Hsu, and Chang (2013) because they have also found supported results regarding mediating effect of work motivation with performance using different predictors. Thereby confirm the statement perfectionist striving are shown to be highly motivated from their work and their motivation helps them in achieving higher task performance and adopting proactive behavior.

In parallel, last relationship that this study predicted is the moderating role of basic psychological needs as it has been argued on the basis of literature by keeping in view the selfdetermination theory Ryan and Deci (2000) that basic psychological needs moderate the mediating effect of work motivation between perfectionist striving and task performance and proactive 
behavior such that this relationship is stronger when needs are satisfied at high level as compared to low. Hypothesis $4 \mathrm{a} \&$ hypothesis $4 \mathrm{~b}$ was not supported as results could not support this moderation. Therefore, could not support the argument given by Gagné and Deci (2005) that work environment that facilitates fulfillment of these needs increases intrinsic motivation of employees and will encourage full externalization of extrinsic motivation which will in return help in achieving positive outcomes such as job satisfaction, persistence \& maintained behavior, effective performance especially on task and other positive work related behaviors. Our results are inconsistent with the results of Wei, Shaffer, Young, and Zakalik (2005)who found partial support of basic psychological needs but as mediator not as a moderator.

\subsection{Managerial Implications}

Beside all this contribution, this study has certain managerial implications as bundle of work by different scholars have considered perfectionism as negative construct because it leads toward depression, stress, anxiety and much more. However, recent research has conceptualized perfectionism into two dimensions as perfectionist striving a positive one and perfectionist concern a negative one. Thus, not all aspects of perfectionism are neurotic, unhealthy, or maladaptive. On the contrary, striving for perfection can form part of a healthy pursuit of excellence (Shafran, Cooper, \& Fairburn, 2002). Therefore, first of all, perfectionism should be considered as positive attitude because it relates to adaptive outcome and positive work behaviours such as performance. Attitude of being perfect or strive to be perfect is very much important for today's employees because with this attitude in mind, people will always strive to get perfection in their work which will help them in achieving important work-related outcomes. Furthermore, work motivation is also important for employees to perform well. They will do best when they will be motivated by their work environment. Therefore, employing organizations should provide it to their employees if they want to enjoy smooth functioning in organization.

\subsection{Limitations \& Directions for Future Research}

Despite of having much strength, this study has also some weaknesses that can be best address by future research scholars in order to have more and thorough understanding of all these processes.

First, this study is totally cross sectional where data has been collected only single time because of shortage of resources. As it is all about the effect of having spirit of perfection on performance of employees, future scholars are required to conduct longitudinal design. Second, we have used single method of data that is quantitative so there can be the possibility of self-report bias. In order to avoid this biasness and also as future is of mix method, so next generations are suggested to conduct this study using mixed method or triangulation by selecting multiple/mixed samples from different cities. In this way, findings will be more valid and reliable. Third, results supported the mediating relationship of work motivation between perfectionist striving and proactive behavior as there can be many other workplace attitudes and behaviors such as job commitment and much more, so future researchers should work out in this regard. They can also check other mediators as well as per the context. Forth, Future scholars may use "role of attribution" as moderator between work motivation and performance. For example, what will be their reaction when they are not motivated by their work place? Will they still perform better because of having the spirit of perfection? Or their reaction will be change?

\section{References:}

Arain, G. A., Hameed, I., \& Farooq, O. (2012). Integrating workplace affect with psychological contract breach and employees' attitudes. Global Business and Organizational Excellence, 31(6), 50-62.

Ahmed, U., Isa, N. M., Majid, A. H. A., Zin, M. L. M., \& Amin, B. M. (2017). Towards understanding work engagement: can HR really buffer HR? Test of a moderated model. International Journal of Economic Research, 14(20), 1-18. 
Ahmed, U., Mozammel, S., \& Ahmed, H. (2018). Performance on the road: examining the critical role of training effectiveness amongst the blue-collar employees in Bahrain. Asian Journal of Empirical Research, 8(9), 342351.

Ahmed, U., Majid, A., Al-Aali, L., \& Mozammel, S. (2019). Can meaningful work really moderate the relationship between supervisor support, coworker support and work Engagement?. Management Science Letters, 9(2), $229-242$.

Ahmed, U., Khalid, N., Islam, DMZ., \& Abro, Z. (2019). Abuse, emotions, and workload in the distribution business: Implications for employees`engagement. International Journal of ADVANCED AND APPLIED SCIENCES, 6(8), 90-99.

Baron, R. A. (1991). Motivation in work settings: Reflections on the core of organizational research. Motivation and Emotion, 15(1), 1-8.

Bateman, T. S., \& Crant, J. M. (1993). The proactive component of organizational behavior: A measure and correlates. Journal of Organizational behavior, 14(2), 103-118.

Becherer, R. C., \& Maurer, J. G. (1999). The proactive personality disposition and entrepreneurial behavior among small company presidents. Journal of Small Business Management, 37(1), 28.

Bieling, P. J., Israeli, A., Smith, J., \& Antony, M. M. (2003). Making the grade: The behavioural consequences of perfectionism in the classroom. Personality and Individual Differences, 35(1), 163-178.

Blankstein, K. R., \& Winkworth, G. R. (2004). Dimensions of perfectionism and levels of attributions for grades: Relations with dysphoria and academic performance. Journal of Rational-emotive and Cognitive-behavior Therapy, 22(4), 267-295.

Blatt, S. J. (1995). The destructiveness of perfectionism: Implications for the treatment of depression. American psychologist, 50(12), 1003.

Broeck, A., Vansteenkiste, M., Witte, H., Soenens, B., \& Lens, W. (2010). Capturing autonomy, competence, and relatedness at work: Construction and initial validation of the Work-related Basic Need Satisfaction scale. Journal of occupational and organizational psychology, 83(4), 981-1002.

Campbell, S. M. (2007). The Best of Intentions: Understanding the Motivational Forces Influencing an Employee's Intent to Leave (or Not Leave) the Current Organization. University of Georgia.

Crant, J. M. (1995). The Proactive Personality Scale and objective job performance among real estate agents. Journal of applied psychology, 80(4), 532.

Crant, J. M. (2000). Proactive behavior in organizations. Journal of Management, 26(3), 435-462.

Damian, L. E., Stoeber, J., Negru, O., \& Băban, A. (2013). On the development of perfectionism in adolescence: Perceived parental expectations predict longitudinal increases in socially prescribed perfectionism. Personality and Individual Differences, 55(6), 688-693.

De Dreu, C. K., Nijstad, B. A., \& van Knippenberg, D. (2008). Motivated information processing in group judgment and decision making. Personality and social psychology review, 12(1), 22-49.

Deci, E. L., \& Ryan, R. (2002). Overview of self-determination theory: An organismic dialectical perspective. Handbook of self-determination research, 3-33.

Deci, E. L., \& Ryan, R. M. (2002). Handbook of self-determination research: University Rochester Press.

Deci, E. L., \&Ryan, R. M. (2008). Self-determination theory: A macrotheory of human motivation, development, and health. Canadian Psychology/Psychologie canadienne, 49(3), 182.

Faye, C., \& Sharpe, D. (2008). Academic motivation in university: The role of basic psychological needs and identity formation. Canadian Journal of Behavioural Science/Revue canadienne des sciences du comportement, 40(4), 189. 
Flett, G. L., \& Hewitt, P. L. (2002). Perfectionism and maladjustment: An overview of theoretical, definitional, and treatment issues.

Frazier, P. A., Tix, A. P., \& Barron, K. E. (2004). Testing moderator and mediator effects in counseling psychology research. Journal of Counseling Psychology, 51(1), 115.

Frese, M., Fay, D., Hilburger, T., Leng, K., \& Tag, A. (1997). The concept of personal initiative: Operationalization, reliability and validity in two German samples. Journal of occupational and organizational psychology, 70, 139-162.

Frese, M., Kring, W., Soose, A., \& Zempel, J. (1996). Personal initiative at work: Differences between East and West Germany. Academy of management journal, 39(1), 37-63.

Fritz, C., \& Sonnentag, S. (2007). Antecedents of day-level proactive behavior: A look at job stressors and positive affect during the workday. Journal of Management.

Frost, R. O., Marten, P., Lahart, C., \& Rosenblate, R. (1990). The dimensions of perfectionism. Cognitive therapy and research, 14(5), 449-468.

Gagné, M., \& Deci, E. L. (2005). Self-determination theory and work motivation. Journal of Organizational behavior, 26(4), 331-362.

Gagné, M., Forest, J., Gilbert, M.-H., Aubé, C., Morin, E., \& Malorni, A. (2010). The Motivation at Work Scale: Validation evidence in two languages. Educational and psychological measurement, 70(4), 628-646.

Galdeano, D., Ahmed, U., Fati, M., Rehan, R., \& Ahmed, A. (2019). Financial performance and corporate social responsibility in the banking sector of Bahrain: Can engagement moderate?. Management Science Letters, 9(10), 1529-1542.

Greenhaus, J. H., Parasuraman, S., \& Wormley, W. M. (1990). Effects of race on organizational experiences, job performance evaluations, and career outcomes. Academy of management journal, 33(1), 64-86.

Griffin, M., Neal, A., \& Neale, M. (2000). The contribution of task performance and contextual performance to effectiveness: Investigating the role of situational constraints. Applied Psychology, 49(3), 517-533.

Hair, J., Black, W., Babin, B., \& Anderson, R. (2010). Multivariate data analysis: a global perspective: Pearson Education.

Hall, H., Hill, A., \& Appleton, P. (2012). Perfectionism: A foundation for sporting excellence or an uneasy pathway toward purgatory?

Hameed, I., Roques, O., \& Arain, G. A. (2013). Nonlinear moderating effect of tenure on organizational identification (OID) and the subsequent role of OID in fostering readiness for change. Group \& Organization Management, 1059601112472727.

Hayes, A. F. (2013). Introduction to mediation, moderation, and conditional process analysis: A regression-based approach: Guilford Press.

Hollender, M. (1978). Perfectionism, a neglected personality trait. The Journal of clinical psychiatry, 39(5), 384.

Ilardi, B. C., Leone, D., Kasser, T., \& Ryan, R. M. (1993). Employee and Supervisor Ratings of Motivation: Main Effects and Discrepancies Associated with Job Satisfaction and Adjustment in a Factory Setting1. Journal of Applied Social Psychology, 23(21), 1789-1805.

Kanfer, R., Chen, G., \& Pritchard, R. (2008). The three C's of work motivation: Content, context, and change. Work motivation: Past, present, and future, 1-16.

Latham, G. P., Ganegoda, D. B., \& Locke, E. A. (2011). A State Theory, but Related to Traits. The Wiley-Blackwell handbook of individual differences, 579.

Latham, G. P., \& Pinder, C. C. (2005). Work motivation theory and research at the dawn of the twenty-first century. Annu. Rev. Psychol., 56, 485-516. 
Liang, C., Hsu, Y., \& Chang, C.-C. (2013). Intrinsic motivation as a mediator on imaginative capability development. Thinking Skills and Creativity, 8, 109-119.

Madrid, D., Ahmed, U., \& Kumar, R. (2019). EXAMINING THE IMPACT OF CLASSROOM ENVIRONMENT ON ENTREPRENEURSHIP EDUCATION: CASE OF A PRIVATE UNIVERSITY IN BAHRAIN. Journal of Entrepreneurship Education, 22(1), 1-8.

Maslow, A. H. (1943). A theory of human motivation. Psychological review, 50(4), 370-396.

McGregor, D. (1960). The human side of enterprise. New York, 21, 166.

Mills, J. S., \& Blankstein, K. R. (2000). Perfectionism, intrinsic vs extrinsic motivation, and motivated strategies for learning: A multidimensional analysis of university students. Personality and individual differences, 29(6), 1191-1204.

Morrison, E. W., \& Phelps, C. C. (1999). Taking charge at work: Extrarole efforts to initiate workplace change. Academy of management journal, 42(4), 403-419.

Motowildo, S. J., Borman, W. C., \& Schmit, M. J. (1997). A theory of individual differences in task and contextual performance. Human performance, 10(2), 71-83.

Nekoie-Moghadam, M., Beheshtifar, M., \& Mazrae-Sefidi, F. (2012). relationship between employees' perfectionism and their creativity. African Journal of Business Management, 6(12), 4659-4665.

Ng, J. Y., Ntoumanis, N., Thøgersen-Ntoumani, C., Deci, E. L., Ryan, R. M., Duda, J. L., \& Williams, G. C. (2012). Self-determination theory applied to health contexts a meta-analysis. Perspectives on Psychological Science, $7(4), 325-340$.

North, E., \& De Vos, R. (2002). The use of conjoint analysis to determine consumer buying preferences: a literature review. Journal of Family Ecology and Consumer Sciences= Tydskrif vir Gesinsekologie en Verbruikerswetenskappe, 30, p. 32-39.

Pacht, A. R. (1984). Reflections on perfection. American psychologist, 39(4), 386-390.

Pahi, M. H., Hamid, K. A., Ahmed, U., \& Umrani, W. A. (2015). The unresolved dilemma of leadershipcommitment relationship: A proposed framework. Business and Economics Journal, 7(1), 2-7.

Pallant, J. (2007). A step-by-step guide to data analysis using SPSS version 15. Open University Press, Maidenhead.

Parker, S. K., Williams, H. M., \& Turner, N. (2006). Modeling the antecedents of proactive behavior at work. Journal of applied psychology, 91(3), 636.

Prather, C. W., \& Turrell, M. C. (2002). Involve everyone in the innovation process. Research Technology Management, 45(5), 13.

Preacher, K. J., \& Hayes, A. F. (2008). Asymptotic and resampling strategies for assessing and comparing indirect effects in multiple mediator models. Behavior research methods, 40(3), 879-891.

Preacher, K. J., Rucker, D. D., \& Hayes, A. F. (2007). Addressing moderated mediation hypotheses: Theory, methods, and prescriptions. Multivariate behavioral research, 42(1), 185-227.

Raja, U., Johns, G., \& Ntalianis, F. (2004). The impact of personality on psychological contracts. Academy of management journal, 47(3), 350-367.

Richer, S. F., Blanchard, C., \& Vallerand, R. J. (2002). A motivational model of work turnover. Journal of Applied Social Psychology, 32(10), 2089-2113.

Ryan, R. M., \& Deci, E. L. (2000). Self-determination theory and the facilitation of intrinsic motivation, social development, and well-being. American psychologist, 55(1), 68.

Ryan, R. M., \& Deci, E. L. (2003). On assimilating identities to the self: a self-determination theory perspective on internalization and integrity within cultures. 
Ryan, R. M., Kuhl, J., \& Deci, E. L. (1997). Nature and autonomy: An organizational view of social and neurobiological aspects of self-regulation in behavior and development. Development and psychopathology, 9(04), 701-728.

Seibert, S. E., Kraimer, M. L., \& Crant, J. M. (2001). A longitudinal model linking proactive personality and career success. Personnel psychology, 54(4), 845-874.

Shafran, R., Cooper, Z., \& Fairburn, C. G. (2002). Clinical perfectionism: A cognitive-behavioural analysis. Behaviour research and therapy, 40(7), 773-791.

Slade, P. D., Newton, T., Butler, N. M., \& Murphy, P. (1991). An experimental analysis of perfectionism and dissatisfaction. British Journal of Clinical Psychology, 30(2), 169-176.

Stoeber, J. (2012). Perfectionism and performance. Oxford handbook of sport and performance psychology, 294306.

Stoeber, J. (2014). How other-oriented perfectionism differs from self-oriented and socially prescribed perfectionism. Journal of Psychopathology and Behavioral Assessment, 36(2), 329-338.

Stoeber, J., \& Childs, J. H. (2010). The assessment of self-oriented and socially prescribed perfectionism: Subscales make a difference. Journal of Personality Assessment, 92(6), 577-585.

Stoeber, J., \& Eismann, U. (2007). Perfectionism in young musicians: Relations with motivation, effort, achievement, and distress. Personality and Individual Differences, 43(8), 2182-2192.

Stoeber, J., \& Eysenck, M. W. (2008). Perfectionism and efficiency: Accuracy, response bias, and invested time in proof-reading performance. Journal of Research in Personality, 42(6), 1673-1678.

Stoeber, J., Feast, A. R., \& Hayward, J. A. (2009). Self-oriented and socially prescribed perfectionism: Differential relationships with intrinsic and extrinsic motivation and test anxiety. Personality and individual differences, 47(5), 423-428.

Stoeber, J., \& Otto, K. (2006). Positive conceptions of perfectionism: Approaches, evidence, challenges. Personality and social psychology review, 10(4), 295-319.

Stoeber, J., \& Rambow, A. (2007). Perfectionism in adolescent school students: Relations with motivation, achievement, and well-being. Personality and individual differences, 42(7), 1379-1389.

Stoeber, J., \& Stoeber, F. S. (2009). Domains of perfectionism: Prevalence and relationships with perfectionism, gender, age, and satisfaction with life. Personality and individual differences, 46(4), 530-535.

Stoeber, J., Uphill, M. A., \& Hotham, S. (2009). Predicting race performance in triathlon: The role of perfectionism, achievement goals, and personal goal setting. Journal of sport \& exercise psychology, 31(2), 211.

Tabachnick, B., \& Fidell, L. (2007). Multivariate analysis of variance and covariance. Using multivariate statistics, 3, 402-407.

Tremblay, M. A., Blanchard, C. M., Taylor, S., Pelletier, L. G., \& Villeneuve, M. (2009). Work Extrinsic and Intrinsic Motivation Scale: Its value for organizational psychology research. Canadian Journal of Behavioural Science/Revue canadienne des sciences du comportement, 41(4), 213.

Tsui, A. S., Pearce, J. L., Porter, L. W., \& Tripoli, A. M. (1997). Alternative approaches to the employeeorganization relationship: does investment in employees pay off? Academy of Management journal, 40(5), 1089-1121.

Unsworth, K., \& Parker, S. K. (2003). Promoting a proactive and innovative workforce for the new workplace. THE NEW WORKPLACE: A GUIDE TO THE HUMAN IMPACT OF MODERN WORKING PRACTICES, D. Holman, TD Wall, CW Clegg, P. Sparrow, A. Howard, eds., Chichester: John Wiley \& Sons.

Vallerand, R. J. (2007). A hierarchical model of intrinsic and extrinsic motivation for sport and physical activity. 
van Beek, I., Taris, T. W., \& Schaufeli, W. B. (2011). Workaholic and work engaged employees: Dead ringers or worlds apart? Journal of Occupational Health Psychology, 16(4), 468.

Van den Broeck, A., Vansteenkiste, M., De Witte, H., \& Lens, W. (2008). Explaining the relationships between job characteristics, burnout, and engagement: The role of basic psychological need satisfaction. Work \&Stress, 22(3), 277-294.

Van Knippenberg, D. (2000). Work motivation and performance: A social identity perspective. Applied Psychology, 49(3), 357-371.

Van Yperen, N. W. (2006). A novel approach to assessing achievement goals in the context of the $2 \times 2$ framework: Identifying distinct profiles of individuals with different dominant achievement goals. Personality and Social Psychology Bulletin, 32(11), 1432-1445.

Vansteenkiste, M., Simons, J., Lens, W., Sheldon, K. M., \& Deci, E. L. (2004). Motivating learning, performance, and persistence: the synergistic effects of intrinsic goal contents and autonomy-supportive contexts. Journal of personality and social psychology, 87(2), 246.

Wei, M., Shaffer, P. A., Young, S. K., \& Zakalik, R. A. (2005). Adult Attachment, Shame, Depression, and Loneliness: The Mediation Role of Basic Psychological Needs Satisfaction. Journal of Counseling Psychology, 52(4), 591.

(C) 2019 by the author(s). Published by Annals of Contemporary Developments in Management \& HR (ACDMHR), under the terms and conditions of the Creative Commons Attribution (CC BY) license which can be accessed at http://creativecommons.org/licenses/by/4.0. 